FACTA UNIVERSITATIS

Series: Physical Education and Sport, Vol. 17, No 1, 2019, pp. 43 - 56

https://doi.org/10.22190/FUPES180913007M

Research article

\title{
THE RESEARCH OF SKIER MOTIVATIONS AND FACTORS INFLUENCING THE CHOICE OF A SKI DESTINATION
}

\author{
UDC 796.9:379.85
}

\section{Duško Mlađenović1, Saša Virijević Jovanović}

${ }^{1}$ Singidunum University, Belgrade, Serbia

${ }^{2}$ Faculty of Applied Management, Economics and Finance, University Business Academy,

Belgrade, Serbia

\begin{abstract}
The main aim of this research is to explore skiers as a segment of the Serbian tourism market, i.e., their reasons of choosing a ski destination for travel. In order to find the answers about the motives of ski tourists, quantitative research was conducted. The data was collected through a Questionnaire on the reasons ski tourists travel and the factors influencing their choice of ski destination. The research represents a pilot project, conducted on a suitable sample of 92 tourists in the Republic of Serbia. The reasons why ski tourists travel to Serbia are divided into three groups: psychological reasons (active holidays, health, enjoyment, relaxation, self-achievement, fleeing from everyday life, and staying in nature); social reasons (spending time with the family, spending time with friends, getting to know new people, new experiences) and reasons for status and prestige (development / testing of ski skills, desire for recognition, proving oneself to others, social recognition, demonstration of skills). The data were analyzed using software SPSS for Windows version 20. The results are presented by the means of descriptive statistics, and since data were normally distributed, the differences were determined by the means of parametric statistical technique, ANOVA method. The research results showed that in the overall sample the most important reasons for traveling are those of a psychological nature, followed by reasons of a social nature, while for skiers in Serbia status and prestige are the least important reasons.
\end{abstract}

Key words: winter sport tourism, skiing, ski tourism, ski tourist motivation

Received September 13, 2018 / Accepted April 10, 2019

Corresponding author: Duško Mlađenović

Singidunum University, Danijelova 32, 11000 Belgrade, Serbia

Phone: +381 $3094094 \cdot$ E-mail: duskommladjenovic@ gmail.com 


\section{INTRODUCTION}

Within the tourism industry, sports tourism has constituted itself as one of the fastest growing segments during the last decade and it has become a profitable market niche (Brown, Busser, \& Baloglu, 2010). According to one belief, sports tourism consists of all forms of active or passive participation in sports activity on an individual or organized basis for commercial or non-commercial purposes conditioning travelling outside the usual place of residence and work (Hall \& Weiler, 1992; Schwark, 2007; Ross, 2001; Standeven \& De Knop, 1999). One of the most accepted definitions of sports tourism in theory is the definition given by Gibson (1998), according to which sports tourism emphasizes the travelling of individuals outside their place of residence with the goal of engaging in physical activities, watching sports events or seeing the attractions related to sports activities. Škorić and Barotluci (2010) define sports tourism as a specific form of tourism, where sports are the main motive for the travel and stay of tourists in a tourist destination. From the stated definitions of sports tourism, it can be concluded that sports tourism emphasizes both travelling motivated by direct sports engagement (recreational or professional), as well as travelling motivated by attendance of certain sports events or manifestations (Mlađenović \& Virijević, 2018). Hinch and Highman (2001) recognize three types of sport tourists: recreational sport tourists, competitive sport tourists, passive sport tourists. Gammon and Robinson (1997) categorized sport tourists by their reasons for traveling: those who partake in sport as the main reason for travel (primary) and those who partake in sport, while participation is not their main objective for travelling (secondary).

Sports tourism is an important segment of special interest tourism (SIT), where the wish to engage in sports activities at the tourist destination is the key motive of travelling (Weed \& Bull, 2004; Sobry, 2005; De Knop, 1987). Sport tourists make their choice about the tourist destination in relation to a complex set of factors, starting with general tourist motives and up to specific motives related to a certain sport (Moutinho, 1987; Robinson \& Gammon, 2004). Lee (2001) concluded that the choice of tourist destination is perceived as involving greater risk than the purchase of other goods. According to Ibrahim and Jacqueline (2005) a tourist decision is influenced by a two-way relationship between the image that tourists have and satisfaction, and therefore, their intention of making frequent visits. Fluker and Turner (2000) pointed out that the motivation of tourists in sports tourism differs depending on the concrete sports activity in comparison to Weed and Bull (2004) and Serra, Correia, \& Rodrigues Paulo (2015), who described the motivation of tourists as heterogenic regarding the importance and role of sports within the vacation destination. The heterogeneity of tourist motivation is the main reason why today research of the demand for sport tourism is not generalized and comprehensive. Regarding this fact, we have oriented our research towards a specific segment of sports tourism - tourism of winter sports - and within this segment - towards ski tourism.

Winter tourism is primary related to the winter season and dominantly to mountain tourist destinations, although certain forms of winter tourism can be enjoyed in spa and sea tourism destinations. It includes activities such as skiing, ice-skating, snowboarding, sledding and the like.

The components that make a ski tourist destination are: 1) ski products as ski tracks, ski schools, ski guides, rental of ski equipment, service of ski equipment and the like; 
2) accommodation/catering capacities like hotels, motels, apartments, restaurants and the like; 3) other contents of a destination, beside skiing such as entertainment, events shops and the like; 4) infrastructure and services such as transportation, health services, banks, police and the like, and 5) elements of sustainable development such as nature and eco approach, cultural heritage, social structure, design and arrangement of a destination (Flagestad \& Hope, 2001).

Regarding the above stated, the term ski tourist refers to a tourist who travels outside their place of residence, with the intention of engaging in ski activities, as well as of experiencing other attractions related to vacation and stay in a ski tourism destination. Skier visits generally increase in areas that have invested in new lifts, improved base facilities, and expanded ski terrain (Downes, 2015).

According to Huntford (2008), the beginnings of skiing developing into a sport are related to Norway. In 1843 in the local newspaper of the Norwegian port Tromso, an advertisement was published encouraging the interested citizens of the Port of Tromso to join a ski competition, emphasizing the ride along the determined track and the return to the starting point. It was the first recorded advertisement in the history of modern skiing and it marked the beginning of the modern ski era. By the end of the 1800s, skiing techniques and equipment were developed, but also skiing as a sports discipline. However, skiing began to flourish only in the second half of the 1900s, when fully equipped ski stations were built all over Europe.

The relationship between sport and tourism was first mentioned by Howe Martyn (1969), who claimed that games attract people to travel abroad in order to play and to watch. Studies in the field of competitive and recreational skiing date back to the 1970s (Ropert, 2015). Although there is a large number of studies dealing with the characteristics of ski tourists, there are significantly fewer studies analyzing factors in choosing a specific ski destination and differences in the reasons for skiing. Therefore, the main aim of this research is to explore the skiers as a segment of the Serbian tourism market, i.e., their reasons to choose a ski destination for travel. The tourist destination for winter sports is, according to Bieger (2002), a geographical, economic and social unit, consisting of organizations, companies, activities and infrastructure, having as a goal to enable the satisfaction of specific needs of winter sports tourists.

Beside the stated, this research aims to fulfill the existing knowledge of skier motivations, as well as to identify the resources of ski destinations that have the greatest importance for ski tourists in Serbia. The research started with two key research questions: what are the main reasons why skiers travel and which factors influence the decision of ski tourists on their choice of tourist destination?

\section{METHODS}

\section{Participants}

The research was conducted on the sample of 92 ski tourists on the territory of the Republic of Serbia. When selecting a sample, it was taken into consideration that the participants had some ski experience, regardless on the level of knowledge of skiing skills.

The study used a stratified random sample technique. A number of participants were randomly selected from each stratum determined by the level of knowledge of skiing skills (Richards, 1996). This technique was chosen because the sample of participants is homogenous 
and had to be divided into subgroups, as follows: beginner skiers, experienced skiers and midlevel skiers. Kothari (2005) recommends the technique of the stratified random sample, because it is accurate, accessible as it can be divided into relevant layers, and it enables a better comparison. Besides that, the advantage of this sampling technique is enabling the participation of subgroups, which otherwise would be completely shut out by other sampling techniques, due to low presence in the population. The sample is relatively equable according to gender, so we can treat sex as an independent variable and examine whether there are important differences in terms of factors influencing the ski destination, as well as in the structure for the reason for travelling, depending on half of the participants.

The sample of participants is also relatively uniform with regard to the variable level of education, with a certain smaller number of participants who had completed their MBA or $\mathrm{PhD}$ studies. The majority of participants $(45.7 \%)$ possess an initial level of skiing skills, followed by middle level skiers $(30.4 \%)$ and experienced skiers $(23.9 \%)$. The sample structure according to the level of skiing skills is presented in Table 1.

Table 1 Sample structure according to skiing skills

\begin{tabular}{lcccc}
\hline Level of ski skills & Frequency & Percentage & $\begin{array}{c}\text { Valid } \\
\text { Percentage }\end{array}$ & $\begin{array}{c}\text { Cumulative } \\
\text { Percentage }\end{array}$ \\
\hline Beginner skiers & 42 & 45.7 & 45.7 & 45.7 \\
Mid-level skiers & 28 & 30.4 & 30.4 & 76.1 \\
Experienced skiers & 22 & 23.9 & 23.9 & 100.0 \\
\hline Total & 92 & 100.0 & 100.0 & \\
\hline
\end{tabular}

\section{Procedures}

The primary phase of data collection was a critical analysis of the existing literature and the results of previous research were compiled in order to form the basis on which the survey questions were developed.

The second phase of the research, in which the primary data were collected, was carried out from December 2016 to January 2017, on the territory of cities of Belgrade, Novi Sad and Kragujevac, as well as the ski destinations Zlatar, Kopaonik and Zlatibor. At the beginning of each interview, the participants were given the opportunity to become familiar with the procedure, the purpose and objectives of the research, as well as the manner in which the data were obtained. They were also told how to fill out the questionnaires.

The first part of the questionnaire is composed of data on the socio-demographic characteristics of the participants and the level of knowledge of skiing skills (Beard \& Ragheb, 1980; Ryan \& Glendon, 1998). The second part contains 17 statements related to different motives of ski tourists, followed by variants of the participants' responses on the Likert scale. The third part of the questionnaire contains 16 statements related to factors influencing the choice of ski destinations, also followed by the variants of the responses on the five-step Likert scale which contains a questionnaire with 5 statements related to the views of the participants about the importance of environmental protection in the ski destination, as well as awareness of the relationship between climate change and ski destinations. For each of the above mentioned 38 statements, the participant should indicate their degree of agreement, which is presented as a grade from 1 to 5 (meaning: $1=\mathrm{I}$ completely disagree; $2=\mathrm{I}$ do not agree; $3=\mathrm{I}$ am not sure; $4=\mathrm{I}$ agree and $5=$ I completely 
agree). The statements contained by the questionnaire on ski tourist motives and factors influencing the choice of a ski destination are created based on the examination of the research stated in the second theoretical part of the paper.

The statements on the motives of ski tourists are grouped into three categories: psychological motives (active vacation, health, enjoyment, relaxation, self-achievement, escape from everyday life and spending time in nature); social motives (spending time with family, spending time with friends, meeting of new people, new experiences) and status and prestigious motives (development/testing of ski skills, the desire to obtain recognition, proving oneself to others, social recognition, demonstration of capabilities).

The statements on factors influencing the destination of choice relate to: the natural environment (landscape, relief, depth of snow cover and length of the winter season); ski infrastructure (length of ski tracks, diversity of ski tracks, and ski lifts); accommodation capacities (sort and type of the accommodation, accommodation category); additional content (spa centers, Pools, social and night life, ice-skating halls, sledding tracks, malls); distance of the destination and price as well as environmental protection (consciousness on the influence of climate changes, relation of the destination to environmental protection, artificial snow) (Hudson \& Ritchie, 2001).

\section{Statistical analysis}

The data were analyzed using SPSS for Windows version 20. The results are presented by the means of descriptive statistics, and the parametric statistical technique ANOVA method, since the data were normally distributed. The significance of the differences was set at the level $\leq 0.05$ (Palant, 2009).

\section{RESULTS}

\section{Research Question 1 - What are the main reasons why skiers travel?}

The first research question was related to the main reasons why ski tourists travel in Serbia. The Questionnaire contained 17 statements on psychological, social, and reasons of status and prestige.

Table 2 shows the arithmetic means of the participants' answers about the psychological reasons for travelling. It is noted that psychological reasons have high values of arithmetic meanings on a five-step scale. Among the psychological reasons for traveling, the most important reason is Enjoying, and then Relaxing, followed by Health and Spending Time in Nature, and immediately afterwards Active Vacation. Self-esteem and Escape from everyday life are less important reasons for skiers deciding to travel in Serbia.

Table 2 Importance of Psychological Reasons for Travelling

\begin{tabular}{lccccccc}
\hline $\begin{array}{l}\text { Psychological } \\
\text { Reasons }\end{array}$ & $\begin{array}{c}\text { Active } \\
\text { Vacation }\end{array}$ & Health Enjoying Relaxation & $\begin{array}{c}\text { Self- } \\
\text { achievement }\end{array}$ & $\begin{array}{c}\text { Escape from } \\
\text { everyday life }\end{array}$ & $\begin{array}{c}\text { Spending } \\
\text { time in nature }\end{array}$ \\
\hline Arithmetic Mean & 4.25 & 4.34 & 4.57 & 4.41 & 3.18 & 3.78 & 4.34 \\
\hline
\end{tabular}


The study of social reasons for traveling of ski tourists has shown that spending time with family and spending time with friends are among the most common reasons for traveling, the strongest in terms of intensity, and the most important (Table 3). Also, it can be noted that the arithmetic means of the social reasons for traveling are lower compared to the psychological reasons for traveling, which means that the psychological reasons for traveling are more important to skiers when making a decision to travel.

Table 3 Importance of Social Reasons for Traveling

\begin{tabular}{lcccc}
\hline $\begin{array}{l}\text { Social Reasons } \\
\text { of Traveling }\end{array}$ & $\begin{array}{c}\text { Spending time } \\
\text { with family }\end{array}$ & $\begin{array}{c}\text { Spending time } \\
\text { with friends }\end{array}$ & $\begin{array}{c}\text { New } \\
\text { experiences }\end{array}$ & $\begin{array}{c}\text { Meeting of new } \\
\text { people }\end{array}$ \\
\hline Arithmetic Mean & 4.04 & 3.95 & 3.79 & 3.41 \\
\hline
\end{tabular}

From table 4 it can be concluded that the reasons of status and prestige do not represent important reasons why ski tourists travel in Serbia. This group of reasons for traveling distinguishes itself only for the development of skiing skills as a reason that can have an impact on ski tourists' decision to travel.

Table 4 Importance of Traveling Reasons Related to Status and Prestige

\begin{tabular}{lccccc}
\hline $\begin{array}{l}\text { Status and } \\
\text { Prestige }\end{array}$ & $\begin{array}{c}\text { Development } \\
\text { of ski skills }\end{array}$ & $\begin{array}{c}\text { Proving } \\
\text { to others }\end{array}$ & $\begin{array}{c}\text { Wish to gather } \\
\text { recognition }\end{array}$ & $\begin{array}{c}\text { Social } \\
\text { recognition }\end{array}$ & $\begin{array}{c}\text { Demonstration of } \\
\text { capabilities }\end{array}$ \\
\hline Arithmetic Mean & 3.63 & 1.61 & 2.01 & 1.68 & 1.94 \\
\hline
\end{tabular}

\section{Research Question 2 - Which factors influence the decision of ski tourists} on their choice of tourist destination?

The second research question from this study is related to factors that influence one's decision when choosing a ski destination. In this respect, factors related to the attributes of ski destinations are examined.

Table 5 Importance of factors influencing the choice of ski destination

\begin{tabular}{lc}
\hline Attributes of Ski Destinations & Arithmetic Mean \\
\hline Landscape & 4.06 \\
Relief & 3.77 \\
Depth of Snow Cover & 3.98 \\
Length of Winter Season & 3.92 \\
Length of Ski Tracks & 3.68 \\
Diversity of Ski Tracks & 3.96 \\
Capacity of Ski Lifts & 3.93 \\
Sort and Type of Accommodation & 4.04 \\
Accommodation Category & 3.81 \\
Social and Night Life & 3.22 \\
Ice-skating ring and sledge tracks & 3.5 \\
Destination distance & 3.75 \\
Service Price & 4.33 \\
\hline
\end{tabular}

The results presented in table 5 show that the most important factor in choosing a ski destination among ski tourists in Serbia is the price of the services. These findings are in 
correlation with Hudson (2000) who credits the economic downturn in the early 1990's for the decline in participation rates in skiing. The next factors that have a major impact on the choice of ski destinations are Landscape and Nature and Sport and Type of Accommodation, followed by factors related to the height and length of the snow cover, the variety of ski trails and the capacity of ski lifts.

\section{Differences in Importance of Psychological Reasons for Traveling \\ Compared to the Level of Knowledge of Skiing Skills}

Table 6 shows the importance of the psychological reasons for the travel of ski tourists in relation to the variable of level of knowledge of skiing skills. The degree of importance for each psychological cause of travel is determined by the height of the arithmetic middle for each group of skiers according to the level of skiing skills and the arithmetic means or the entire sample, which is designated as the sum for each psychological reason of the trip. On the basis of arithmetic means, the enjoyment (AS - 4.86), relaxation (AS - 4.41) and stay in nature (AS 4.35) are the most important psychological reasons seen for the whole sample.

Table 6 Importance of psychological reasons for travel related to the level of skiing skills

\begin{tabular}{|c|c|c|c|c|c|c|c|c|}
\hline \multirow[t]{3}{*}{$\begin{array}{l}\text { Travel } \\
\text { Reasons }\end{array}$} & \multirow[t]{3}{*}{ Ski Skills Level } & \multirow[t]{3}{*}{$\mathrm{N}$} & \multirow[t]{3}{*}{ Mean } & \multirow[t]{3}{*}{ SD } & \multicolumn{2}{|c|}{$\begin{array}{l}95 \% \text { Confidence } \\
\text { Interval for Mean }\end{array}$} & \multirow[t]{3}{*}{ Min } & \multirow[t]{3}{*}{ Max } \\
\hline & & & & & Lower & Upper & & \\
\hline & & & & & Bound & Bound & & \\
\hline \multirow{4}{*}{$\begin{array}{l}\text { Active } \\
\text { vacation }\end{array}$} & Beginner skiers & 42 & 4.00 & .82639 & 3.7425 & 4.2575 & 1.00 & 5.00 \\
\hline & Mid-level skiers & 28 & 4.36 & .67847 & 4.0941 & 4.6202 & 2.00 & 5.00 \\
\hline & Experienced skiers & 22 & 4.59 & .50324 & 4.3678 & 4.8140 & 4.00 & 5.00 \\
\hline & Total & 92 & 4.25 & .75046 & 4.0946 & 4.4054 & 1.00 & 5.00 \\
\hline \multirow{4}{*}{ Health } & Beginner skiers & 42 & 4.24 & .75900 & 4.0016 & 4.4746 & 1.00 & 5.00 \\
\hline & Mid-level skiers & 28 & 4.36 & .55872 & 4.1405 & 4.5738 & 3.00 & 5.00 \\
\hline & Experienced skiers & 22 & 4.55 & .73855 & 4.2180 & 4.8729 & 2.00 & 5.00 \\
\hline & Total & 92 & 4.35 & .70219 & 4.2024 & 4.4932 & 1.00 & 5.00 \\
\hline \multirow{4}{*}{ Enjoyment } & Beginner skiers & 42 & 4.38 & .76357 & 4.1430 & 4.6189 & 1.00 & 5.00 \\
\hline & Mid-level skiers & 28 & 4.64 & .55872 & 4.4262 & 4.8595 & 3.00 & 5.00 \\
\hline & Experienced skiers & 22 & 4.86 & .35125 & 4.7079 & 5.0194 & 4.00 & 5.00 \\
\hline & Total & 92 & 4.58 & .65017 & 4.4414 & 4.7107 & 1.00 & 5.00 \\
\hline \multirow{4}{*}{ Relaxation } & Beginner skiers & 42 & 4.24 & .98301 & 3.9318 & 4.5444 & 1.00 & 5.00 \\
\hline & Mid-level skiers & 28 & 4.46 & .74447 & 4.1756 & 4.7530 & 2.00 & 5.00 \\
\hline & Experienced skiers & 22 & 4.68 & .56790 & 4.4300 & 4.9336 & 3.00 & 5.00 \\
\hline & Total & 92 & 4.41 & .84062 & 4.2390 & 4.5871 & 1.00 & 5.00 \\
\hline \multirow{4}{*}{$\begin{array}{l}\text { Self- } \\
\text { Achievement }\end{array}$} & Beginner skiers & 42 & 3.38 & 1.01097 & 3.0659 & 3.6960 & 1.00 & 5.00 \\
\hline & Mid-level skiers & 28 & 2.96 & 1.07090 & 2.5490 & 3.3795 & 1.00 & 5.00 \\
\hline & Experienced skiers & 22 & 3.09 & 1.41115 & 2.4652 & 3.7166 & 1.00 & 5.00 \\
\hline & Total & 92 & 3.19 & 1.13805 & 2.9491 & 3.4205 & 1.00 & 5.00 \\
\hline \multirow{4}{*}{$\begin{array}{l}\text { Escape from } \\
\text { everyday life }\end{array}$} & Beginner skiers & 42 & 3.93 & 1.04515 & 3.6029 & 4.2543 & 1.00 & 5.00 \\
\hline & Mid-level skiers & 28 & 3.57 & 1.16837 & 3.1184 & 4.0245 & 2.00 & 5.00 \\
\hline & Experienced skiers & 22 & 3.77 & 1.34277 & 3.1774 & 4.3681 & 1.00 & 5.00 \\
\hline & Total & 92 & 3.78 & 1.15622 & 3.5432 & 4.0221 & 1.00 & 5.00 \\
\hline \multirow{4}{*}{$\begin{array}{l}\text { Spending time } \\
\text { in nature }\end{array}$} & Beginner skiers & 42 & 4.35 & .75938 & 4.1205 & 4.5938 & 1.00 & 5.00 \\
\hline & Mid-level skiers & 28 & 4.35 & .67847 & 4.0941 & 4.6202 & 2.00 & 5.00 \\
\hline & Experienced skiers & 22 & 4.31 & 1.08612 & 3.8366 & 4.7997 & 1.00 & 5.00 \\
\hline & Total & 92 & 4.35 & .81786 & 4.1785 & 4.5172 & 1.00 & 5.00 \\
\hline
\end{tabular}


Table 7 Difference in importance of psychological reasons for travel of ski tourists related to level of skiing skills

\begin{tabular}{|c|c|c|c|c|c|c|}
\hline Psychological & avel reasons & Sum of & $\mathrm{df}$ & Mean & $\mathrm{F}$ & Sig. \\
\hline & Between groups & 5.503 & 2 & 2.752 & 5.353 & .006 \\
\hline Active & Within groups & 45.747 & 89 & .514 & & \\
\hline & Total & 51.250 & 91 & & & \\
\hline & Between groups & 1.367 & 2 & .684 & 1.399 & .252 \\
\hline Health & Within groups & 43.502 & 89 & .489 & & \\
\hline & Total & 44.870 & 91 & & & \\
\hline & Between groups & 3.543 & 2 & 1.772 & 4.515 & .014 \\
\hline Enjoyment & Within groups & 34.924 & 89 & .392 & & \\
\hline & Total & 38.467 & 91 & & & \\
\hline & Between groups & 2.948 & 2 & 1.474 & 2.138 & .124 \\
\hline Relaxation & Within groups & 61.356 & 89 & .689 & & \\
\hline & Total & 64.304 & 91 & & & \\
\hline & Between groups & 3.171 & 2 & 1.586 & 1.231 & .297 \\
\hline Self- & Within groups & 114.687 & 89 & 1.289 & & \\
\hline & Total & 117.859 & 91 & & & \\
\hline & Between groups & 2.146 & 2 & 1.073 & .799 & .453 \\
\hline Escape from & Within groups & 119.506 & 89 & 1.343 & & \\
\hline & Total & 121.652 & 91 & & & \\
\hline & Between groups & .025 & 2 & .013 & .019 & .982 \\
\hline Stay in nature & Within groups & 60.844 & 89 & .684 & & \\
\hline & Total & 60.870 & 91 & & & \\
\hline
\end{tabular}

Table 7 presents the analysis of variance which shows the possible existence of statistically significant differences in the importance of psychological reasons, i.e., whether skiers of different skill levels of skiing significantly differ in terms of importance of the individual psychological reasons of the trip. The variance analysis showed that in terms of the importance of the psychological reasons for traveling in relation to the level of knowledge of skiing skills, a statistically significant difference exists only in respect to two reasons for traveling, namely: active vacation and enjoyment, between the groups of experienced skiers and beginner skiers.

\section{Differences in the importance of social reasons for travel related to skiing skills levels}

Table 8 presents the data related to the importance of social reasons for traveling (spending time with family, spending time with friends, getting to know new people, new experiences) compared to the level of knowledge of skiing skills.

The degree of importance of every social cause of travel is determined by the height of the arithmetic means. On the basis of the arithmetic means it can be said that the time spent with family (AS - 4.04) and spending time with friends (AS - 3.96) are the most important social factors when it comes to the whole sample of ski tourists. Table 9 shows whether there are statistically significant differences between the social reasons of travel, i.e., whether skiers of a distinct skill level differ significantly according to the importance they give to certain social reasons for travel. 
Table 8 Importance of social reasons for travel related to the level of skiing skills

\begin{tabular}{|c|c|c|c|c|c|c|c|c|}
\hline $\begin{array}{l}\text { Social } \\
\text { travel } \\
\text { reasons }\end{array}$ & $\begin{array}{l}\text { Level of knowledge of } \\
\text { skiing skills }\end{array}$ & $\mathrm{N}$ & Mean & SD & \multicolumn{2}{|c|}{$\begin{array}{l}\text { 95\% Confidence } \\
\text { Interval for Mean }\end{array}$} & Min & $\operatorname{Max}$ \\
\hline \multirow{4}{*}{$\begin{array}{l}\text { Spending } \\
\text { time with } \\
\text { family }\end{array}$} & Beginner skiers & 42 & 4.10 & 1.00752 & 3.7813 & 4.4092 & 1.00 & 5.00 \\
\hline & Mid-level skiers & 28 & 4.14 & .70523 & 3.8694 & 4.4163 & 3.00 & 5.00 \\
\hline & Experienced skiers & 22 & 3.82 & 1.33225 & 3.2275 & 4.4089 & 1.00 & 5.00 \\
\hline & Total & 92 & 4.04 & 1.01541 & 3.8332 & 4.2538 & 1.00 & 5.00 \\
\hline \multirow{4}{*}{$\begin{array}{l}\text { Spending } \\
\text { time with } \\
\text { friends }\end{array}$} & Beginner skiers & 42 & 4.17 & .76243 & 3.9291 & 4.4043 & 1.00 & 5.00 \\
\hline & Mid-level skiers & 28 & 3.86 & .70523 & 3.5837 & 4.1306 & 2.00 & 5.00 \\
\hline & Experienced skiers & 22 & 3.68 & 1.17053 & 3.1628 & 4.2008 & 1.00 & 5.00 \\
\hline & Total & 92 & 3.96 & .87597 & 3.7751 & 4.1379 & 1.00 & 5.00 \\
\hline \multirow{4}{*}{$\begin{array}{l}\text { Meeting } \\
\text { new people }\end{array}$} & Beginner skiers & 42 & 3.74 & .93859 & 3.4456 & 4.0306 & 1.00 & 5.00 \\
\hline & Mid-level skiers & 28 & 3.25 & 1.04083 & 2.8464 & 3.6536 & 1.00 & 5.00 \\
\hline & Experienced skiers & 22 & 3.00 & 1.19523 & 2.4701 & 3.5299 & 1.00 & 5.00 \\
\hline & Total & 92 & 3.41 & 1.07061 & 3.1913 & 3.6348 & 1.00 & 5.00 \\
\hline \multirow{4}{*}{$\begin{array}{l}\text { New } \\
\text { experiences }\end{array}$} & Beginner skiers & 42 & 3.98 & .86920 & 3.7053 & 4.2471 & 1.00 & 5.00 \\
\hline & Mid-level skiers & 28 & 3.79 & .83254 & 3.4629 & 4.1085 & 2.00 & 5.00 \\
\hline & Experienced skiers & 22 & 3.46 & 1.18431 & 2.9295 & 3.9796 & 1.00 & 5.00 \\
\hline & Total & 92 & 3.79 & .95547 & 3.5956 & 3.9914 & 1.00 & 5.00 \\
\hline
\end{tabular}

Table 9 Differences in the importance of social reasons depending on skiing skills

\begin{tabular}{lcrrrrr}
\hline \multicolumn{1}{c}{ Social reasons } & & $\begin{array}{c}\text { Sum of } \\
\text { Squares }\end{array}$ & Df & $\begin{array}{c}\text { Mean } \\
\text { Square }\end{array}$ & F & Sig. \\
\hline \multirow{2}{*}{ Spending time with } & Between groups & 1.506 & 2 & .753 & .726 & .487 \\
family & Within groups & 92.320 & 89 & 1.037 & & \\
& Total & 93.826 & 91 & & & \\
\hline \multirow{2}{*}{ Spending time with } & Between groups & 3.791 & 2 & 1.896 & 2.555 & .083 \\
friends & Within groups & 66.035 & 89 & .742 & & \\
& Total & 69.826 & 91 & & & \\
\hline \multirow{3}{*}{ Meeting new people } & Between groups & 8.935 & 2 & 4.468 & 4.169 &. $\mathbf{0 1 9}$ \\
& Within groups & 95.369 & 89 & 1.072 & & \\
& Total & 104.304 & 91 & & & \\
\hline \multirow{3}{*}{ New experiences } & Between groups & 3.931 & 2 & 1.966 & 2.210 & .116 \\
& Within groups & 79.145 & 89 & .889 & & \\
\hline & Total & 83.076 & 91 & & & \\
\hline
\end{tabular}

The first thing to notice on the basis of statistically significant differences between groups in terms of the importance of the sociological reasons for traveling is that the reason for new people to get acquainted with a group of beginner skiers is significantly more important than for experienced skiers. Again, in view of the fact that skiing is a new experience in every respect, it was expected that the participants from this group will be different from the other two groups in terms of the reasons that are decisive when making the decision to travel. It is evident that more skilled skiers, that is, those with a middle level knowledge of skiing skills and experienced skiers are not very interested in new acquaintances, but in reasons such as active vacation and recreation. This is the only statistically significant difference in the significance of the sociological reasons for the 
skiers' travel in relation to the level of skiing skills. Regardless of the fact that there is no statistical significance, it is also important to look at other sociological reasons for travel. Thus new experiences are also the most important for beginners. This can be a significant indicator in terms of the complexity of this category of ski tourists, as they are not too demanding because most things related to ski tourism are new and interesting. Getting new experiences out of the skiing context is least important to the more experienced skiers. The same is the situation with regard to spending time with friends and family, because this is also the reason for the trip, which is important for beginner skiers, while skiers with a medium level of skiing skills and experienced skiers find it less important to spend time with friends and family during their trip.

\section{Differences in the importance of status and prestige reasons related to the level of skiing skills}

Status and prestige as the reasons for traveling have been operationalized through the development and testing of skiing skills, the desire to gain recognition, achievement, proving oneself to others, social recognition and demonstration of capabilities, and this section will examin how these reasons are important to skiers when making their decision to travel.

Table 10 shows the degree of importance of every reason for status and prestige that is determined by the height of the arithmetic means for each individual group of skiers and the arithmetic means for the entire sample of ski tourists designated as sums for every

Table 10 Importance of status and prestige reasons related to the level of skiing skills

\begin{tabular}{|c|c|c|c|c|c|c|c|c|}
\hline \multirow[t]{2}{*}{$\begin{array}{l}\text { Status and } \\
\text { prestige reasons }\end{array}$} & \multirow[t]{2}{*}{$\begin{array}{c}\text { Ski skills level } \\
\text { knowledge }\end{array}$} & \multirow[t]{2}{*}{$\mathrm{N}$} & \multirow[t]{2}{*}{ Mean } & \multirow[t]{2}{*}{ SD } & \multicolumn{2}{|c|}{$\begin{array}{l}\text { 95\% Confidence } \\
\text { Interval for Mean }\end{array}$} & \multirow[t]{2}{*}{ Min } & \multirow[t]{2}{*}{$\operatorname{Max}$} \\
\hline & & & & & $\begin{array}{l}\text { Lower } \\
\text { Bound }\end{array}$ & $\begin{array}{l}\text { Upper } \\
\text { Bound }\end{array}$ & & \\
\hline \multirow{4}{*}{$\begin{array}{l}\text { Development } \\
\text { and testing of } \\
\text { ski skills }\end{array}$} & Beg & 42 & 3.74 & .96423 & 3.4376 & 4.0386 & 1.00 & 5.00 \\
\hline & Mid & 28 & 3.43 & .92009 & 3.0718 & 3.7853 & 1.00 & 5.00 \\
\hline & Experienced skiers & 22 & 3.68 & 1.21052 & 3.1451 & 4.2185 & 1.00 & 5.00 \\
\hline & To & 92 & 3.63 & 1.01329 & 3.4206 & 3.8403 & 1.00 & 5.00 \\
\hline \multirow{4}{*}{$\begin{array}{l}\text { Wish for } \\
\text { recognition }\end{array}$} & Beginner skiers & 42 & 2.19 & 1.08736 & 1.8516 & 2.5293 & 1.00 & 5.00 \\
\hline & Mid- & 28 & 1.89 & .99403 & 1.5074 & 2.2783 & 1.00 & 4.00 \\
\hline & Experienc & 22 & 1.82 & .85280 & 1.4401 & 2.1963 & 1.00 & 3.00 \\
\hline & Total & 92 & 2.01 & 1.01087 & 1.8015 & 2.2202 & 1.00 & 5.00 \\
\hline \multirow{4}{*}{$\begin{array}{l}\text { Proving to } \\
\text { others }\end{array}$} & Beginner skie & 42 & 1.67 & .72134 & 1.4419 & 1.8915 & 1.00 & 3.00 \\
\hline & Mid & 28 & 1.61 & .83174 & 1.2846 & 1.9297 & 1.00 & 4.00 \\
\hline & Experi & 22 & 1.55 & .73855 & 1.2180 & 1.8729 & 1.00 & 3.00 \\
\hline & Total & 92 & 1.62 & .75363 & 1.4635 & 1.7756 & 1.00 & 4.00 \\
\hline \multirow{4}{*}{$\begin{array}{l}\text { Social } \\
\text { recognition }\end{array}$} & Beginner skiers & 42 & 1.71 & .77415 & 1.4730 & 1.9555 & 1.00 & 4.00 \\
\hline & Mid-level skiers & 28 & 1.61 & .87514 & 1.2678 & 1.9465 & 1.00 & 4.00 \\
\hline & Experienced skiers & 22 & 1.73 & .88273 & 1.3359 & 2.1187 & 1.00 & 4.00 \\
\hline & Total & 92 & 1.69 & .82448 & 1.5140 & 1.8555 & 1.00 & 4.00 \\
\hline \multirow{4}{*}{$\begin{array}{l}\text { Demonstration } \\
\text { of capabilities }\end{array}$} & Beginner sl & 42 & 1.95 & .90937 & 1.6690 & 2.2358 & 1.00 & 4.00 \\
\hline & Mid-level skiers & 28 & 1.75 & .88715 & 1.4060 & 2.0940 & 1.00 & 4.00 \\
\hline & Experienced skiers & 22 & 2.18 & 1.00647 & 1.7356 & 2.6281 & 1.00 & 4.00 \\
\hline & Total & 92 & 1.95 & .93013 & 1.7530 & 2.1383 & 1.00 & 4.00 \\
\hline
\end{tabular}


reason of status and prestige. We see that arithmetic means are the reason for status and prestige significantly lower than variables concerning psychological and social reasons. The only variable with a higher arithmetic means is the development and testing of skiing skills (AS - 3.63). Below is table 11 with the results of the the ANOVA that show the possible existence of statistically significant differences, i.e., whether skiers of different levels of skiing skills differ significantly in terms of the importance they give to certain reasons of status and prestige when they make their decision to travel.

The results of the ANOVA method in Table 11 show that there are no statistically significant differences between groups regarding the importance of the reasons of status and prestige. It can also be seen that deviations from the arithmetic means are minimal and that the values of the arithmetic means themselves are low. Based on the arithmetic means, the very reason for this is importance - the development and testing of skiing skills, which is most important to experienced skiers, as well as beginner and middle-level skiers. This is the only reason for status and prestige that can be considered as equally important for the psychological and social reasons of travel according to the values of the arithmetic means. Therefore, as a problem of status and prestige, it can be concluded that they are not an important reason for travel of ski tourists.

Table 11 Differences in importance of the status and prestige reason related to the level of skiing skills

\begin{tabular}{lcccccc}
\hline $\begin{array}{l}\text { Reasons of status } \\
\text { and prestige }\end{array}$ & Sum of & Df & $\begin{array}{c}\text { Mean } \\
\text { Square }\end{array}$ & F & Sig. \\
\hline \multirow{2}{*}{$\begin{array}{l}\text { Development and } \\
\text { Sesting of ski skills }\end{array}$} & Between groups & 1.506 & 1.686 & 2 & .843 & .818 \\
& Within groups & 92.320 & 91.749 & 89 & 1.031 & \\
& Total & 93.826 & 93.435 & 91 & & \\
\hline \multirow{3}{*}{ Wish for recognition } & Between groups & 3.791 & 2.562 & 2 & 1.281 & 1.261 \\
& Within groups & 66.035 & 90.427 & 89 & 1.016 & \\
& Total & 69.826 & 92.989 & 91 & & \\
\hline \multirow{3}{*}{ Proving to others } & Between groups & 8.935 & .218 & 2 & .109 & .189 \\
& Within groups & 95.369 & 51.466 & 89 & .578 & \\
& Total & 104.304 & 51.685 & 91 & & \\
\hline \multirow{3}{*}{ Social recognition } & Between groups & 3.931 & .245 & 2 & .123 & .177 \\
& Within groups & 79.145 & 61.614 & 89 & .692 & \\
\hline \multirow{2}{*}{$\begin{array}{l}\text { Demonstration of } \\
\text { capabilities }\end{array}$} & Between groups & 83.076 & 61.859 & 91 & & \\
\hline & Within groups & 92.320 & 76.427 & 89 & .859 & \\
\hline & Total & 93.826 & 78.728 & 91 & & \\
\hline
\end{tabular}

\section{DISCUSSION}

The subject of this paper is to examine the Serbian ski tourism segment and to identify the reasons why ski tourists in Serbia travel and the factors that influence their choice of ski destination. The survey sample included 92 skiers from the territory of the Republic of Serbia, divided into three sub-samples based on the level of their skiing skills: beginner skiers (42\%), skiers with a medium level knowledge of ski skills (30.4\%) and experienced skiers $(23,9 \%)$.

The reasons of the ski tourists traveling in Serbia are divided into three groups: psychological reasons (active holidays, health, enjoyment, relaxation, self-achievement, 
fleeing from everyday life, and staying in nature); social reasons (spending time with the family, spending time with friends, getting to know new people, new experiences) and reasons of status and prestige (development / testing skiing skills, desire for recognition, proving oneself to others, social recognition, demonstration of skills).

The research results showed that in the overall sample the most important reasons for traveling are those of a psychological nature, followed by reasons of a social nature, while for the skiers in Serbia the least important reasons are status and prestige. The arithmetic means on a five-step scale, which reflects the importance of a particular reason for traveling, for an active holiday is 4.59 , for enjoying 4.86 for the category of experienced skiers, and they are thus distinguished from the remaining two categories. But if we look at the arithmetic means of all the reasons of a psychological nature, we can see that active rest, health, enjoyment and relaxation have arithmetic means above 4 for all categories of skiers, that is, for all the participants. When it comes to social reasons, the results showed that time spent with the family and spending time with friends have arithmetic means of over 4 in beginner and middle-level skier categories.

The factors influencing the choice of ski destinations are divided into six categories: a natural environment (landscape, relief, snow cover, and length of the winter season); ski infrastructure (length of ski slopes, variety of ski trails, ski lifts, and cable cars); accommodation capacities (sort and type of accommodation, the category of accommodation); additional facilities (spa centers, swimming pools, social and night life, ice rinks and sledding trails, shopping centers); distance of the destination and prices, and environmental protection (awareness of the impact of climate change, the relation of the destination towards environmental protection, artificial snow). The findings of the survey showed that the most important factors influencing the choice of ski destinations are the price of services, the sort and type of accommodation, the height of the snow covers, the length of the ski track, the variety of ski trails, and the capacity of ski lifts.

Regarding the differences in the reasons of travel and the factors influencing the choice of ski destinations, the results of the survey confirmed the assumption that the level of skiing skills is the most important variable. Skiing as a way to spend a holiday can be a personal challenge and can be a goal in itself. For experienced skiers, the most important is an active holiday and enjoyment, which is provided by the variety, difficulty and length of the ski slopes, as the most important factors for selecting the ski destination. For the subgroup of beginner skiers the most important reason is enjoyment, relaxation, spending time with family and friends, and getting to know new people. For skiers with a middle level knowledge of skiing skills, the trip is seen as a traditional gathering of family and friends for the mutual enjoyment of skiing and additional recreational and tourist content.

\section{CONCLUSION}

The findings of the study show that, in the overall sample, the most important reasons for traveling are the reasons of psychological nature (enjoyment, relaxation, active holidays and health, staying in nature). Also, the research results indicate the importance of social reasons for traveling, as a large number of skiers travel to spend quality time with friends and family. When it comes to reasons for traveling regarding status and prestige, we came to the conclusion that among ski tourists in Serbia, these reasons have 
no significance when deciding about a journey. Among the factors influencing the choice of ski destinations, the most important factors are the price of services, the sort and type of the accommodation, and then the quality of the snow cover, the length and variety of ski trails and the capacity of ski lifts, as well as additional facilities: spa centers, swimming pools, shopping centers and ice rinks, and trails for sledding. The most important findings of the research relate to the significant differences among skiers in relation to the level of their ski skills, both in terms of the reasons they are traveling and in terms of the factors that are decisive for their choice of ski destinations.

However, it is necessary to point out certain limitations of this research, having in mind that during the research process, the researcher was not able to include the proportional participation of all three groups of skiers in the sample, and that the dominant group was that of beginner skiers. In that sense, the research findings are most relevant for this group of participants. Therefore, one of the recommendations for further research can be the necessity of a wider study of the differences in the reasons for travel and the factors influencing the choice of ski destinations in relation to the level of skiing skills, in order to obtain reliable data.

\section{REFERENCES}

Beard, J., \& Ragheb, M. (1980). Measuring leisure satisfaction. Journal of Leisure Research, 12 (20), 33

Bieger, T. (2002). Management von Destinationen (Management of destinations). München: Oldenburg Verlag. In German

Brown, C., Busser, J.A., \& Baloglu, S. (2010). Sport tourists in a gaming destination: Predicting gaming and non-gaming expenditures. UNLV Gaming Research \& Review Journal, 14(2), 59.

De Knop, P. (1987). Some thoughts on the influence of sport tourism. In M. Garmise (Ed.). Proceedings of the international seminar and workshop on outdoor education, recreation and sport tourism, (pp. 38-45). Netenya, Israel: Wingate Institute for Physical Education and Sport.

Downes, J. (2015). Resort Development - Tourism is the Driver-Cooperative Spirit is the Key. UNWTO.

Flagestad, A., \& Hope, C.A. (2001). Strategic success in winter sports destinations: a sustainable value creation perspective. Tourism Management, 22(5), 445-461.

Fluker, M.R., \& Turner, L.W. (2000). Needs, motivations, and expectations of a commercial whitewater rafting experience. Journal of Travel Research, 38(4), 380-389.

Gammon, S. \& Robinson, T. (1997). Sport tourism: A conceptual framework. Journal of Sport Tourism, 4(3), 11-18.

Gibson, H. (1998). Active sport tourism: Who participates? Leisure Studies, 17, 155-170.

Hall, C., \& Weiler, B. (1992). Special Interest Tourism. London: Belhaven.

Hinch, T.D., \& Higham J.E.S. (2001). Sport tourism: a framework for research. The International Journal of Tourism Research, 3(1), 45-58.

Huntford, R. (2008). Two planks and a passion: The dramatic history of skiing. London: Continuum.

Hudson, S., \& Ritchie, B. (2001). Cross-cultural tourist behavior: An analysis of tourist attitudes towards the environment. Journal of Travel \& Tourism Marketing, 10(2), 1-22.

Hudson, S. (2000). Snow business. London: Continuum Publishing Group.

Ibrahim, E.E., \& Jacqueline G. (2005). A positioning strategy for a tourist destination, based on analysis of customers' perceptions and satisfactions. Marketing Intelligence \& Planning, 23(2/3), 172-187.

Kothari, C.R. (2005). Research methodology: Methods \& techniques. New Delhi: New Age International (P) Ltd. Kothari.

Lee, G. (2001). Constructs of tourists' destination loyalty and market segmentation. PhD Dissertation. Indiana, USA: Perdue University.

Martyn, H. (1969). The influence of sports on international tourism. Business and Society, 9(2), 38-44.

Mlađenović D., \& Virijević Jovanović S. (2018). Behavioural characteristics of skiers as tourist. Berlin: Scholars' Press.

Moutinho, L (1987). Consumer behaviour in tourism. European Journal of Marketing, 21(10), 5-7. 
Palant, J. (2009). SPSS priručnik za preživljavanje (SPSS Survival manual). In M. Olga (Ed.). Belgrade: Mikro knjiga. In Serbian

Ross, S.D. (2001). Developing sports tourism, an e guide for destination marketers and sports events planners. (pp.3-10). Illinois: National Laboratory for Tourism and eCommerce.

Ropert, R. (2015). Limiting factors for success in alpine skiing. Facta Universitatis Series Physical Education and Sport, 13(2), 167-176.

Robinson, T., \& Gammon, S. (2004). A question of primary and secondary motives: revisiting and applying the sport tourism framework. Journal of Sport \& Tourism, 9(3), 221-233.

Richards, G. (1996). Skilled consumption and UK ski holidays. Tourism Management, 17(1), 25-34

Ryan, C., \& Glendon, I. (1998). Application of leisure motivation scale to tourism. Annals of Tourism Research, 25(1), 169-184.

Schwark J. (2007). Sport tourism: introduction and overview. European Journal for Sport and Society, $4(2), 117-132$

Serra, J., Correia, A., \& Rodrigues Paulo, M.M. (2014). Heterogeneity in tourism motivations: The case of the Algarve. In A.G. Woodside, \& M. Kozak (Eds.) Tourists' behaviors and evaluations: Advances in culture, tourism and hospitality research, Volume 9, (pp. 85-95). Emerald Group Publishing Limited.

Sobry, C. (2005). Le tourisme sportif. (pp.13-30). Lille: Presses Universitaires du Septentrion.

Standeven, J., \& De Knop, P. (1999). Sport tourism. Champaign: Human Kinetics.

Škorić, S., \& Bartoluci, M. (2010). Značaj stručnjaka sportske rekreacije u turizmu (The importance of sports recreation specialists in tourism). In V. Findak (Ed.). Proceedings book 19th summer school of kinesiologists of Republic of Croatia - Individualisation of work in area of education, sport, sport recreation and kinesitherapy, Poreč, (pp. 569-574). Zagreb: Hrvatski kineziološki savez. In Croatian

Weed, M., \& Bull, C. (2004). Sports tourism: Participants, policy and providers. Oxford: ButterworthHeinemann.

\section{ISTRAŽIVANJE MOTIVACIJE SKIJAŠA I FAKTORA KOJI UTIČU NA IZBOR SKIJAŠKE DESTINACIJE}

Osnovni cilj ovog istraživanja je da se istraže skijaši koji sačinjavaju segment srpskog turističkog tržišta, odnosno njihovi razlozi za izbor skijaške destinacije i putovanja. Da bi se pronašli odgovori o motivima skijaša-turista, sprovedeno je kvantitativno istraživanje, a podaci su prikupljeni putem upitnika o razlozima putovanja skijaša-turista i faktorima koji utiču na izbor skijaške destinacije. Istraživanje predstavlja pilot projekat koji se sprovodi sa odgovarajućem uzorkom ispitanika kojeg sačinjava 92-oje turista u Republici Srbiji. Razlozi zbog kojih skijaši-turisti biraju Srbiju podeljeni su u tri grupe: psihološki razlozi (aktivni odmor, zdravlje, uživanje, opuštanje, samopostignuće, beg od svakodnevnog života i boravak u prirodi); socijalni razlozi (druženje sa porodicom, druženje sa prijateljima, upoznavanje novih ljudi, nova iskustva) i razlozi za status i prestiž (razvoj/testiranje skijaških vještina, želja za priznanjem, dokazivanje drugima, društveno priznanje, demonstracija veština). Podaci su analizirani korišćenjem softvera SPSS za Windows verzija 20. Rezultati su predstavljeni deskriptivno, a obzirom da su su podaci normalno distribuirani, razlike su utvrđivane parametarskom statističkom tehnikom, ANOVA metodom. Rezultati istraživanja su pokazali da su u ukupnom uzorku najvažniji razlozi za putovanje psihološke prirode, praćeni razlozima socijalne prirode, dok su za skijaše u Srbiji status i prestiž najmanje bitni razlozi.

Ključne reči: zimski sportski turizam, skijanje, ski turizam, motivacija skijaškog turizma 